Review

\title{
Prevention of Protein Glycation by Natural Compounds
}

\section{Izabela Sadowska-Bartosz ${ }^{1, *}$ and Grzegorz Bartosz ${ }^{1,2}$}

1 Department of Biochemistry and Cell Biology, University of Rzeszow, Zelwerowicza St. 4, PL 35-601 Rzeszow, Poland

2 Department of Molecular Biophysics, University of Lodz, Pomorska St. 141/143, 90-236 Lodz, Poland

* Author to whom correspondence should be addressed; E-Mail: isadowska@poczta.fm; Tel.: +48-17-785-5408; Fax: +48-17-872-1425.

Academic Editor: Maurizio Battino

Received: 17 December 2014 / Accepted: 11 February 2015 / Published: 16 February 2015

\begin{abstract}
Non-enzymatic protein glycosylation (glycation) contributes to many diseases and aging of organisms. It can be expected that inhibition of glycation may prolong the lifespan. The search for inhibitors of glycation, mainly using in vitro models, has identified natural compounds able to prevent glycation, especially polyphenols and other natural antioxidants. Extrapolation of results of in vitro studies on the in vivo situation is not straightforward due to differences in the conditions and mechanism of glycation, and bioavailability problems. Nevertheless, available data allow to postulate that enrichment of diet in natural anti-glycating agents may attenuate glycation and, in consequence, ageing.
\end{abstract}

Keywords: glycation; inhibitors of glycation; ageing

\section{Glycation}

Louis Camille Maillard (1912) first reported that reducing sugars react with amino acids in solution producing dark-colored products (melanoidins) [1]. Similar chemical reactions could be observed also in solutions of reducing sugars mixed with peptides and proteins. This reaction, called now the "Maillard reaction", is a complex network of successive and parallel reactions. Initially,a sugar having the functionality of the aldehyde group, or an aldehyde, reacts non-enzymatically with a thiol or amino groups of a protein (or another biomolecule) forming a Schiff base. Comparison of reactivity of various amino acid residues in peptides with reducing sugars revealed the highest reactivity of side chains of 
cysteine, lysine, and histidine, and amino groups of the N-terminal amino acids [2]. The Schiff bases rearrange over a period of days to produce ketoamine or Amadori products. The Amadori products undergo dehydration and rearrangements followed by other reactions such as cyclisation, oxidation, and dehydration to form more stable Advanced Glycation End Products (AGEs) [3]. Dicarbonyl products, glyoxal and methylglyoxal, formed as intermediate products in the course of the Maillard reaction, are of great importance. These highly active compounds, which are also formed in the cell as by-products of glycolysis, can react with proteins producing cross-links resistant to the action of enzymes. Carboxymethyl-lysine (CML), a non-fluorescent protein adduct, was first described by Ahmed and represents the most prevalent AGE in vivo [4]. Pentosidine (a fluorescent glycoxidation product) was first isolated and characterized by Sell and Monnier [5]. Other AGEs identified in vivo include glucosepane, carboxymethyl-hydroxylysine, carboxyethyllysine (CEL), fructose-lysine, and pyrraline, which form non-fluorescent protein adducts, fluorescent methylglyoxal-derived hydroimidazolone (MGH1), which contributes significantly to skin fluorescence [6], and glyoxal-lysine dimer and methylglyoxal-lysine dimer forming non-fluorescent protein crosslinks [7]. Glycation alters the structure and functional properties of proteins, which affects adversely cellular metabolism.

AGE formation takes place under normal physiologic conditions but is accelerated in hyperglycemia [8-10]. AGEs may also form from non-glucose sources including lipid and amino acid oxidation $[9,11,12]$. Increased level of reactive oxygen species (ROS) cause oxidative stress; in analogy, increased concentration of sugars (glucose, deoxyglucose, fructose, ribose and triose phosphates) and active dicarbonyl compounds (glyoxal and methylglyoxal) can cause "carbonyl stress" resulting in the increased rate of formation of AGEs.

Among all the natural monosaccharides, glucose is characterized by the maximal shift of the equilibrium between the cyclic and aldehyde isoforms (only $0.2 \%$ existing in the aldehyde form). Thus, glucose is one of the least active sugars in relation to glycation and this property might have been the reason for the evolutionary choice of glucose as the universal carbohydrate energy carrier [13].

AGEs accumulate intracellularly mainly because of their generation from glucose-derived dicarbonyl precursors formed in the course of metabolism [14,15]. Although it is possible that intracellular AGEs can play positive roles as stimuli for activating intracellular signaling pathways and modifying the function of intracellular proteins, there is a plethora of evidence that their accumulation adversely affects protein structure and function. Cytoskeletal proteins are important in providing stability of the cytoskeleton and are crucially involved in numerous cellular functions such as migration and cellular division. Various other intracellular proteins including enzymes and growth factors may be targets of non-enzymatic modification by sugars. Glycated basic fibroblast growth factor (bFGF) displays impaired mitogenic activity in endothelial cells [14]. Glycation of enzymes of the ubiquitin-proteasome system and of the lysosomal proteolytic system has been shown to inhibit their action [16]. The structural components of the connective tissue matrix and basement membrane components (e.g., type IV collagen) as well as other long-lived proteins (including myelin, tubulin, plasminogen activator 1 and fibrinogen) can also undergo advanced glycation [17]. It should be mentioned that AGE-modified proteins may be more resistant to enzymatic degradation [18].

Accumulation of glycation products is associated with various diseases including, first of all, diabetes and diabetic nephropathy, microangiopathy and atherosclerosis [12]. Indeed, the intermolecular collagen cross-linking caused by AGEs leads to diminished arterial and myocardial compliance and increased 
vascular stiffness, phenomena that are considered to explain partly the increase in diastolic dysfunction and systolic hypertension seen in diabetic patients [19]. Yuen et al. (2010) suggested that collagen glycation augments the formation and migration of myofibroblasts and participates in the development of fibrosis in diabetes [20]. Other studies showed that glycated collagen alters the endothelial cell function and could be an important factor in atherosclerotic plaque development [21]. More recently, it was revealed that AGEs may act as mediators of the progression of stable to rupture-prone plaques; this finding opens a window towards biomarkers and novel treatments of cardiovascular diseases [22].

A significant effect of AGEs involves their interactions with receptors (receptors for AGEs or RAGEs and others). Interaction of AGEs with RAGEs generates secondary oxidative stress and plethora of other undesired effects including increased gene transcription of pro-inflammatory and pro-fibrotic cytokines and chemokines leading to an inflammatory condition [23], which, in turn, in many instances, promotes epithelial cell malignant transformation, contributing to tumorigenesis [24]. Shortened RAGEs (sRAGEs) circulating in blood and body fluids, which lack the transmembrane domain, include an endogenous secretory isoform generated via alternative splicing and a form generated through proteolytic cleavage of the full-length cell surface receptor, serve as competitive binding sites for AGEs diminishing their effects on RAGEs [12].

There is a relationship between activation of the AGE-RAGE system and some aspects of polycystic ovary syndrome (PCOS), such as granulosa cell dysfunction, adipocyte pathophysiology, obesity and insulin resistance. Furthermore, irregular ovarian AGE signaling might in part explain the abnormal ovarian histology observed in women with PCOS [25].

The serum level of AGEs has been found to be elevated in such diseases as cystic fibrosis [26], non-B or non-C hepatocellular carcinoma [27], relapsing-remitting multiple sclerosis [28,29] or schizophrenia [30]. It should be mentioned that glycation induces refolding of initially globular albumin into amyloid fibrils comprising cross- $\beta$ structure [31]. Moreover, glycation induces the formation of the $\beta$-sheet structure in $\beta$-amyloid protein, $\beta$-synuclein, transthyretin, as well as copper-zinc superoxide dismutase. Aggregation of the $\beta$-sheet structure in the brain creates fibrillar structures, respectively causing Alzheimer's disease, Parkinson's disease, amyotrophic lateral sclerosis, familial amyloid polyneuropathy and prion disease. It has been also suggested that oligomeric species of glycated $\alpha$-synuclein and prion are more toxic than fibrils [32].

A controversy remains regarding the content of AGEs as a biochemical marker of Alzheimer's disease. Thome and co-workers (1996) examined the question whether the reported increased level of AGEs in the brain is reflected in an increase in AGE-associated parameters in peripheral blood [33]. These authors reported that elevated central nervous system AGEs levels in patients with Alzheimer's disease are manifested without detectable peripheral changes, however other investigators demonstrated moderate increases in Amadori products of plasma proteins [34]. A more recent study revealed a lower level of circulating serum AGEs in patients with Alzheimer's disease in relation to healthy controls [35].

In addition, literature data indicate that accumulation of AGEs plays an important role in the development of degenerative changes in the lens of the eye, leading to blindness or cataract. Progression of cataract is increased in patients with diabetes mellitus [36]. AGEs induce irreversible structural changes in the protein, resulting in the formation of protein aggregates of high molecular weight, which impede vision and light scatter [37]. It has been shown that AGEs, by altering the surface charge of the protein, lead to conformational changes and consequently reduces the transparency of the lens of the 
eye [38]. AGEs also play an important role in the progression of diabetic retinopathy leading to dysfunction or death of retinal cells [39]. Recent reports indicate that detoxification of methylglyoxal reduces the accumulation of AGEs, which in turn can prevent the pathological changes in the retina and vessels [40].

\section{Glycation and Ageing}

Glycation has been repetitively proposed to contribute to the process of ageing. Accumulation of products of protein glycation with ageing has been observed [8,41]. In the early 1980s, after AGEs had been found to accumulate with age in tissues of living organisms, a theory of "non-enzymatic glycosylation as the cause of ageing" was proposed [42]. Many age-related deteriorative changes are actually due to protein degradation, such as posttranslational modification, accumulation of molecular waste, deterioration of functional proteins, functional disorders of the tricarboxylic acid cycle, or activation of inflammatory pathways by intracellular signals. All of these changes are symptomatic of "glycation stress" [43]. AGEs are metabolized by protease and oxidized protein degradation enzymes, such as oxidized protein hydrolase, in the proteasome and then excreted [44]. Other enzymes are also known to modify AGEs and intermediate compounds. For example, glyoxalase 1 is the key enzyme that converts the highly reactive $\alpha$-oxo-aldehydes into the corresponding $\alpha$-hydroxy acids using L-glutathione as a cofactor. Unfortunately, the activity of proteolytic enzymes decreases with age $[41,45]$. Most recent studies revealed that AGEs are mitogenic compounds and trigger cell cycle reentry of neurons in Alzheimer's disease brain. The reduction of oxidative stress by application of $\alpha$-lipoic acid decreased AGEs accumulations, and this decrease was accompanied by a reduction in cell cycle reentry and a more euploid neuronal genome [46].

Galactose is much more effective than glucose as a glycating agent amount of aldehyde for many times exceeds that of glucose [47]. Addition of galactose to the diet was shown to cause typical premature ageing, in which the mitochondrial path of apoptosis involving cytochrome $c$ release from mitochondria plays an important role [48]. This effect was attenuated by salidroside, an inhibitor of RAGE-type receptors [49]. Metformin, inhibiting AGEs formation from monosaccharides, is also known to be a geroprotector [2].

At the cellular level, aminoguanidine was shown to increase the replicative lifespan of human lung fibroblasts from 54 up to 75 population doublings (at $4 \mathrm{mM}$ aminoguanidine) and decreased the rate of telomere shortening by more than $50 \%$. While several mechanisms can contribute to this effect, the inhibition of glycation may be significant [50]. It has been postulated that accumulation of AGEs is the basis of "biological clock" governing ontogenesis and ageing [2].

Ageing is associated with a chronic low-grade inflammatory status that contributes to chronic diseases such as age-related muscle wasting, kidney disease, and diabetes mellitus. AGEs are known to be proinflammatory. Intervention studies in humans showed mainly a decrease in inflammation in subjects on a low-AGE diet, while an increase in inflammation in subjects on a high-AGE diet was less apparent [51]. About half of the observational studies found a relationship between inflammatory processes and AGEs in food. The dietary intake of AGEs appears to be related to inflammatory status and the level of circulating AGEs. Limiting AGE intake may lead to a decrease in inflammation and chronic diseases related to inflammatory status [51]. Moreover, lowering the content of AGEs in the 
normal diet significantly prevents AGEs accumulation, attenuates oxidative stress and extends lifespan in mice. In humans, short-term trials demonstrated that a low-AGEs diet reduces oxidant burden and inflammatory markers [8].

\section{Inhibition of Glycation}

Preventive medicine seems to be the best approach to preventing the development of lifestyle-related diseases such as atherosclerosis and diabetic complications. The daily intake of AGEs inhibitors in natural products can play a beneficial role in preventing the pathogenesis of lifestyle-related diseases. Therefore, natural compounds have been screened as potential inhibitors of AGEs formation [52].

A class of compounds is known that prevent the formation of AGEs or degrade the existing AGEs. Some of them have been produced and patented. They include: First of all, aminoguanidine and anti-type 2 diabetes drugs such as metformin and pioglitazone (patented). From among other drugs in use, angiotensin receptor blockers, inhibitors of angiotensin converting enzyme, and pentoxyfylline (patented) were also found to inhibit AGE formation. Other inhibitors of protein glycation include antioxidants, such as vitamin $\mathrm{C}$ and vitamin $\mathrm{E}$, and metal ion chelators (desferoxamine and penicillamine). Aspirin inhibits glycation competitively by capping amino groups. Amadori products already formed may be deglycated by enzymes called amadoriases. A group of compounds has been discovered, which break $\alpha$-dicarbonyl cross-links, among them phenacylthiazolium bromide and its stable derivative ALT-711 (Alagebrium). Finally, derivatives of aryl ureido and aryl carboxaminido phenoxy isobutyric acids (patented) protect against glycation. Some of these compounds such as metformin, pioglitazone, pentoxyfylline and aspirin have already been used in clinical practice, some (aminoguanidine and ALT-711) have been tested in clinical trials [53].

Aminoguanidine was the first AGEs inhibitor discovered in 1986; its mechanism of action involves catching reactive intermediates generated by the Maillard reaction. Animal models of type 1 and 2 diabetes showed that aminoguanidine prevents formation of AGEs and thus diabetic complications, including vascular ones [54]. Aminoguanidine half-life in plasma is short (about $1 \mathrm{~h}$ ), therefore, it must be applied at a relatively high dose $(1 \mathrm{~g} / \mathrm{L}$ of water) to produce a concentration sufficient to trap reactive species [55]. The use of high concentrations of aminoguanidine is not preferred because of its reaction with vitamin B6, which in turn causes a deficiency. Another inhibitor of AGE formation is pyridoxine; its mechanism of action involves blocking the oxidation of compounds formed by the Maillard reaction, catching of reactive oxygen species and reactive carbonyl and dicarbonyl compounds or metal chelates which catalyze the oxidation reactions [56]. Just as aminoguanidine, pyridoxine exhibits inhibitory effect of vascular diseases associated with diabetes, in addition to lowering cholesterol and triglyceride levels [57]. Among other substances acting on the basis of catching reactive carbonyl compounds 2,3-diaminophenazine and penicillamine should be mentioned. However, to date, there are no studies in vivo identifying the reaction products of these substances with the compounds produced during the process of glycation. Thiamine and benfotiamine one have also been described as inhibitors of the formation of AGEs, but their action is limited [58]. Based on the structure of thiamine and benfotiamine one can speculate that they may be effective metal chelators. It seems that research should focus on the selection of those substances that are both inhibitors of AGEs and will chelate metal ions effectively, are nontoxic, and their half-life in vivo is quite long. 
There is a big interest in the search of compounds of natural origin which can inhibit glycation, apart from those already mentioned. Search for such compounds is based, in the first stage, on in vitro screening experiments. However, results of in vitro experiments may be misleading due to several reasons. Most AGEs products are formed by glycooxidative mechanisms that require oxygen and are catalyzed by traces of redox active transition metal ions [59,60]. In vitro assays for AGE formation and inhibition cannot adequately mimic the metal ion distribution or antioxidant and detoxification mechanisms in tissues and their various compartments. Especially, the sugar concentration and oxygen pressure are usually much higher in the in vitro experiments than in vivo. Autooxidation of glucose (Wolff pathway) or Schiff bases (Namiki pathway) may dominate at high glucose in vitro but not at low glucose and high oxygen level in vivo [60].

The complex nature of the Maillard reaction makes it difficult to identify the mechanism of inhibition of glycation. Khalifah et al. proposed a procedure to prepare proteins rich in Amadori compounds but free from AGEs ("pre-glycated" albumin) to identify compounds inhibiting glycation at post-Amadori stage of AGE formation (amadorins). Pyridoxamine, in contrast to aminoguanidine, was found to have amadorin activity [60].

\section{Inhibition of Glycation in Vitro}

The antiglycation properties of numerous medical herbs and dietary plants are of a similar [61] or even higher order $[62,63]$ than that of standard inhibitor of glycoxidation - aminoguanidine. In an in vitro assay, methanol extracts of whole plants of Calendula officinalis and fruits of Juglans regia showed antiglycating activity with respect to bovine serum albumin (BSA) comparable to that of aminoguanidine on the weight concentration basis [61]. 16 compounds were isolated from ethyl acetate extracts of Erigeron annuus, 3,5-di-O-caffeoyl-epi-quinic acid being the most active inhibiting BSA glycation, preventing opacification of lenses and inhibiting aldose reductase [63]. Ethanol extracts of 14 wild berries were compared for their antiglycating activity in vitro. Extract of Empetrum nigrum L. showed the strongest activity; the anti-glycating activity correlated with the radical scavenging activity of the extracts [64]. Comparison of antiglycating activity of eight anthraquinones from the roots of Knoxia valerianoides showed considerable activity of lucidin and 1,3,6-trihydroxy-2methoxymethylanthraquinone [65]. Maltol was also found to have a stronger in vitro AGE inhibiting activity compared with aminoguanidine [62].

In vitro glycation assays showed that a number of polyphenols exerted inhibitory effects on the glycation reaction. Polyphenols are the most abundant antioxidants in our diets. The main classes of polyphenols are phenolic acids (mainly caffeic acid) and flavonoids (the most abundant in the diet are flavanols, especially catechins plus proanthocyanidins), anthocyanins and their oxidation products), which account for one- and two-thirds of dietary polyphenols, respectively. Polyphenols are reducing agents, and together with other dietary antioxidants, such as vitamin $\mathrm{C}$, vitamin $\mathrm{E}$ and carotenoids, protect the body's tissues against oxidative stress and associated pathologies such as cancers, coronary heart disease as well as inflammation [66]. Comparison of the anti-glycating activity in vitro of ethanol/water extracts of coriander, turmeric, scallion, pepper mint, onion, parsley, ginger, curry, scallion, pepper mint, onion and parsley leaves showed a good correlation between the anti-glycating and antioxidant activities of the extracts [67]. 
Phenolic acids are the main polyphenols made by plants. These compounds have diverse functions and are immensely important in plant-microbe interactions/symbiosis. Adisakwattana et al. (2012) found that cinnamic acid and its derivatives could effectively protect BSA from fructose-mediated protein glycation in vitro [68]. Recent investigations suggested that cinnamic acid derivatives such as ferulic acid (3-methoxy-4-hydroxycinnamic acid) and isoferulic acid (3-hydroxy-4-methoxycinnamic acid), which are the main active components of the rhizoma of Cimicifuga heracleifolia, an anti-inflammatory drug used frequently in Japanese traditional medicine, are also AGEs inhibitors [69-71]. The results obtained by Srey et al. (2010) indicated that ferulic acid effectively inhibits CML and CEL formation in model food systems [72]. Silván et al. (2011) reported that ferulic acid at a final concentration of $2.5 \mathrm{mg} / \mathrm{mL}$ exerts a clear anti-glycation effect, mainly due to an inhibition of the advanced stage of the glycation reaction (specific anti-AGE effect) [69]. More recently Meeprom et al. (2013) showed that isoferulic acid (1.25-5 mM) inhibits the formation of fluorescent AGEs and non-fluorescent AGE (CML) and fructosamine protein adducts [71]. It should be noted that isoferulic acid has been found to be a metal ion chelating agent. From this point, metal chelating activity of isoferulic acid might be one of possible mechanism responsible for inhibition of glycation.

Huang et al. (2008) investigated the inhibitory abilities of phenolic acids (chlorogenic acid, syringic acid and vanillic acid) on methylglyoxal-induced mouse Neuro-2A neuroblastoma (Neuro-2A) cell apoptosis in the progression of diabetic neuropathy. The data indicated that methylglyoxal induced mouse Neuro-2A neuroblastoma (Neuro-2A) cell apoptosis via alternation of mitochondria membrane potential and $\mathrm{Bax} / \mathrm{Bcl}-2$ ratio, activation of caspase-3, and cleavage of poly (ADP-ribose) polymerase. Moreover, the results showed that activation of mitogen-activated protein kinase signal pathways (JNK and p38) participated in the methylglyoxal-induced Neuro-2A cell apoptosis process. Thus, treatment of Neuro-2A cells with phenolic acids suppresses cell apoptosis induced by methylglyoxal, suggesting that phenolic acids possess cytoprotective ability in the prevention of diabetic neuropathy complications [73].

Other polyphenols present in many dietary sources also have the anti-glycating activity. For example, ellagic acid (2,3,7,8-tetrahydroxy-chromeno[5,4,3-cde]chromene-5,10-dione) is one of the commonly found dietary polyphenols. Apart from the greatest sources, such as berries and pomegranate, ellagic acid is also present in apples, grapes, orange, guava and cumin. Ellagic acid is known to have antioxidant, anti-inflammatory and anticarcinogenic properties. The antiglycating action of ellagic acid seems to involve, apart from inhibition of a few fluorescent AGEs, predominantly inhibition of CEL through scavenging of the dicarbonyl compounds. Furthermore, MALDI-TOF-MS (matrix assisted laser-desorption ionisation-time-of-flight MS) analysis confirms inhibition of the formation of CEL on lysozyme on in vitro glycation by ellagic acid. Prevention of glycation-mediated $\beta$-sheet formation in hemoglobin and lysozyme by ellagic acid confirm its antiglycating ability [74].

Gugliucci et al. (2009) evaluated the anti-glycation effect of some bioactive substances present in yerba maté (Ilex paraguariensis): 5-caffeoylquinic acid, caffeic acid and sapogenin (oleanolic acid). These authors suggested that chlorogenic acid and caffeic acid are the main substances responsible for the anti-glycation effect of mate tea [75]. Chlorogenic acid is a phenolic compound formed by the esterification of caffeic and quinic acids. The inhibitory effects of chlorogenic acid on AGEs formation and collagen cross-linking may be caused by its interactions with reactive dicarbonyl compounds, such as methylglyoxal. Chlorogenic acid could be expected to be beneficial in the prevention of AGEs 
progression in patients with diabetes [76]; however, no results clinical studies with chlorogenic acid have been published.

Flavonoids (a diverse class of polyphenolic compounds), have been also demonstrated to be effective inhibitors of glycoxidation. The inhibition of glycoxidation has been showed for various polyphenols, including quercetin, genistein, tannic acid and gallic acid [77-81]. Our recent study in vitro on prevention of BSA glycation showed that the same compounds were found to have different effects on glycoxidation induced by various sugars, glyoxal and methylglyoxal, which suggests caution in extrapolation from experiments based on one sugar to other sugars. From among the compounds tested, the most effective inhibitors of glycoxidation were: polyphenols, pyridoxine and 1-cyano-4-hydroxycinnamic acid. As standard antioxidants had a stronger effect than metal chelators, we ascribe the inhibition of BSA glycation by polyphenols mainly to their antioxidant rather than metal-chelating properties $[82,83]$.

Xie and Chen (2013) summarized the structural features of flavonoids relevant for their anti-glycation activity. They concluded that: (i) The hydroxylation on both A ring and B ring improved the inhibitory activity on AGEs formation, while hydroxylation on $\mathrm{C}$ ring decreased the activity; (ii) The methylation generally reduced the anti-AGEs activity of flavonoids, except for the 3-O-methylation of flavonols; (iii) The glycosylation of hydroxyls of flavonoids tended to decrease the inhibitory activities on inhibiting AGEs formation, although contradictory results were also reported; (iv) Hydrogenation of the $\mathrm{C} 2=\mathrm{C} 3$ double bond of flavones slightly weakened their activities; (v) A 5,7-dihydroxy structure was favorable; (vi) Proanthocyanidins dimers or trimers showed a stronger inhibitory activity than catechins, and the glucosides of anthocyanidin had higher activities than their rutinosides; (vii) The hydroxylation on $\mathrm{B}$ ring and the methylation of stilbenes decreased the inhibitory activity; (viii) The presence of galloyl groups was important for the activity of catechins, and $\alpha$-hydroxyl group at C-3 was much more effective than $\beta$-hydroxyl group at C-3; (ix) The phenolic acids with multiple hydroxyls showed strong inhibition of AGEs formation, and an ortho or meta dihydroxyl structure on the benzene ring was vital to the anti-AGEs activity of anthraquinones; (x) Both ellagic acids and ellagitannins showed potent inhibitory activities on AGEs formation, and hydroxylation increased the activities but methylation decreased them [80]. Components of animal-derived diet may also have anti-glycating properties. Carnitine was found to be an effective anti-glycating compound both in vitro and in vivo [84].

The above results suggest that consumption of a polyphenol-rich diet may attenuate protein glycation to some extent, and the addition of polyphenols can be useful in reducing undesired glycoxidation in food processing.

\section{Inhibition of Glycation in Vivo}

\subsection{Reduction of AGE Intake}

Dietary AGEs constitute a significant source of AGEs in the body. AGEs formation can be rapidly accelerated by increasing the time and degree of exposure to heat and can be introduced into the body in heat-processed foods. E. g., pretzel sticks are a rich source of pentosidine and pyrraline [85]. AGEs are also present in the cigarette smoke, are inhaled into the alveoli, and then they are transported to blood stream or to lung cells where they can interact with other glycation products and contribute to protein glycation [86]. While detailed mechanisms of intestinal absorption of AGEs are not fully elucidated, 
it is known, e.g., that pyrraline is absorbed by the peptide transporter hPEPT1 [87]. It has been estimated that ca $10 \%$ of ingested immunoreactive AGEs are transported into circulation, two-thirds of which remain in the body. Exogenous AGEs are incorporated covalently in tissues, and only one third is excreted via the kidneys [88]. A significant correlation between the amount of ingested AGEs and the plasma levels of these compounds was found in humans [89].

It has been controversial whether dietary AGEs are harmful to human health, because these compounds are heterogeneous and only a few have been characterized. Some of the products formed during this intricate reaction are furfurals, pyrralines and dicarbonyl compounds such as methylglyoxal. The products formed in the last reaction of this process are known as melanoidins in food science. CML has been reported as one of the most abundant in vivo and it was one of the first to be characterized in foods (milk and milk products). For this reason in most studies CML is chosen as a marker of AGEs in foods and in vivo [90]. However, long-term consumption of AGEs in rats was found to increase the levels of fasting glucose, insulin and serum AGEs [91], and induced a dose-dependent increase in proteinuria that over time could induce renal damage [92]. In mice, reduced dietary AGEs have been found to attenuate insulin resistance, increase the prevention of diabetes and, in diabetic mice, reduce diabetic vascular and renal complications, and improve impaired wound healing [93].

It should be mentioned that human breast milk contains approximately 70 -fold lower amounts of CML than commercial infant milk and breast-fed infants had significantly lower plasma CML compared to infants fed with commercial infant milk [94].

Human studies demonstrated that intake of dietary AGEs by people with type 1 and 2 diabetes promotes the formation of pro-inflammatory mediators, leading to tissue injury [95]. Patients with uremia, with and without diabetes, in whom the intake of AGEs was reduced, showed reduced levels of inflammatory molecules such as TNF- $\alpha$ and high sensitivity C-reactive protein (hsCRP) [96]. In another study in patients with type 2 diabetes mellitus, decreasing the intake of AGEs for six weeks resulted in decreased levels of circulating AGEs and inflammatory markers [97]. The effects of reducing dietary AGEs have also been studied in nondiabetic peritoneal dialysis patients, a group that has very high AGE levels, and the results showed significant reduction in the levels of AGEs and C-reactive protein [96].

The positive effects of calorie restriction on the lifespan of various animals, especially rodents, are well known, though the generality of this phenomenon has been recently questioned [98]. Calorie restriction involves decrease in the AGE intake. It is possible that reduction in AGE consumption contributes significantly to the beneficial effects of calorie restriction [99].

All these data suggest that reduction of dietary intake of AGEs and reduction or elimination of smoking can contribute to lowering the level of AGEs in the body.

\subsection{Effect of Exogenous Compounds of Natural Origin}

\subsubsection{Problems with Exogenous Modification of Glycation}

Prevention of glycation in vivo is not easy to achieve. Most drugs are enzyme inhibitors of receptor ligands and usually have half-maximal activity at nanomolar to micromolar concentrations. In contrast, glycation inhibitors must react stoichiometrically with low molecular mass, soluble, reactive intermediates of the AGE formation pathway in the presence of much higher concentrations of reactive 
functional groups on proteins. Lysine, for example, which is a major site of chemical modification of proteins by AGEs, is present in plasma proteins at a concentration of nearly $50 \mathrm{mM}$. An AGE inhibitor, which is unlikely to achieve a concentration of even of $100 \mu \mathrm{M}$ in plasma, should be significantly more reactive with intermediates of AGE formation than protein lysine and other reactive residues [100]. Alternatively, the inhibitor may intercept the formation of AGEs at a stage either preceding the formation of the reactive carbonyl intermediates or after formation of a reactive adduct with protein. At the same time, it must display these activities without interfering with the intermediary metabolism of aldehydes or ketones, or trapping coenzymes or their precursors that contain reactive aldehydes, such as pyridoxal phosphate and retinal [101]. Bioavailability of exogenous compounds is an important problem in dietary interventions. Vlassopoulos et al. (2014) carried out a systematic literature review of dietary interventions reporting plasma concentrations of polyphenol metabolites. High dietary polyphenol intake, 3-hydroxyphenylacetic acid is the most abundant phenolic acid in peripheral blood (up to $338 \mu \mathrm{M}$ ) with concentrations of other phenolic acids ranging from $13 \mathrm{nM}$ to $200 \mu \mathrm{M}$ [102].

\subsubsection{Effects of Natural Compounds}

Pyridoxamine (1 $\mathrm{g} / \mathrm{L}$ drinking water) retarded the development of renal disease, measured by increases in urinary albumin and total protein and plasma creatinine, in the streptozotocin (STZ)-induced diabetic rat and inhibited a ca 2-fold increase in CML, CEL, Maillard-type fluorescence, and crosslinking of skin collagen of diabetic rats, compared to non-diabetic controls, after 7 months of diabetes [57]. Another study employing $0.4 \mathrm{~g} / \mathrm{L}$ in drinking water, inhibited modest increases (20\%-25\%) in MOLD (methylglyoxal-lysine dimer) and pentosidine concentration in plasma proteins, and also inhibited a nearly 3-fold increase in plasma and erythrocyte methylglyoxal concentrations [102]. Pyridoxamine retarded also the development of retinopathy in the STZ-diabetic rat, as measured by protection against pericyte loss and formation of acellular capillaries [103]. In Zucker obese (fa/fa) rats, pyridoxamine inhibited the increases in fluorescence, CML, and CEL in skin collagen, increase in malondialdehyde and hydroxynonenal, and retarded early retinopathy as judged from proteinuria and plasma creatinine [104]. A study of the effect of 15 natural flavonoids, stilbenes and caffeic acid oligomers pointed to significant inhibition by all the flavonoids tested, especially hesperidin, naringin, quercetin and kaempferol. Resveratrol, piceatannol, epirabdosin, lithospermic acid and lithospermic acid $\mathrm{B}$ had also anti-glycating activity similar to aminoguanidine [105]. However, polyphenols act also via interference with RAGE signaling; this effect may contribute to the antitumor activity of polyphenols [106] so the effects observed may be contributed by other mechanisms irrespective of inhibition of glycation.

Anti-glycating effect may be simply due to lowering of blood glucose level; such action has been demonstrated, e.g., for methanolic bark extract of Albizia odoratissima Benth. [107].

Recently Li et al. (2014) employed a D-galactose-induced ageing rat model to investigate the protective effect of the saponins from Aralia taibaiensis (Araliaceae). They suggested that, by activating AKT/Forkhead box O3a and nuclear factor-erythroid 2-related factor 2 pathways, saponins supplementation increased the expression and function of their downstream antioxidants, including superoxide dismutase 2, catalase, glutathione reductase, glutathione, glutamate-cysteine ligase, and heme oxygenase 1, at least in part contributing to the protection against D-galactose-induced ageing [108]. It has been also found 
that the oral administration of Asn-Trp or carnosine ( $\beta$-alanyl-L-histidine) dipeptides ameliorates oxidative stress and learning dysfunctions in D-galactose-induced ageing BALB/c mice [109].

Prisila Dulcy et al. (2012) examined the neuroprotective effect of standardized Bacopa monniera extract (BME: BESEB CDRI-08) against the D-galactose (D-gal)-induced brain ageing in rats. These findings suggest that BME treatment attenuates D-gal-induced brain ageing and regulates the level of antioxidant enzymes, NF-E2-related factor 2 expression, and the level of serotonin, which was accompanied by concomitantly increased levels of the presynaptic proteins (synaptotagmin I, synaptophysin) and the postsynaptic proteins $\left(\mathrm{Ca}^{2+} /\right.$ calmodulin dependent protein kinase II) as well as postsynaptic density protein-95 [110].

The administration of $50 \mathrm{mg} / \mathrm{kg}$ per day of maltol suppressed the elevated serum levels of glycosylated protein, renal fluorescent AGEs, CML, receptors for AGEs and nuclear factor-kappaB p65 in diabetic control rats, and protected against renal damage [62]. However, in another study $500 \mathrm{mg} / \mathrm{kg}$ /day epicatechin enhanced rather than decreased the CML accumulation on the surface of gastric epithelial cells in streptozotocin-diabetic mice [111].

Examples of more detailed results of in vivo studies are shown in Table 1.

Stem cells have various potential uses in most medical areas due to their differentiation and paracrine effects. Zhang et al. (2014) reported that adipose-derived stem cells (ASCs) provide a functional benefit by glycation suppression, antioxidation, and trophic effects in a mouse model of ageing induced by D-galactose. They showed that ASCs can decrease the AGE level, therefore reversing the ageing phenotype, which is a similar effect to that of aminoguanidine, and inhibitors of AGEs and ASCs can decrease the expression of senescence-associated markers such as superoxide dismutase and malondialdehyde [112].

\subsubsection{Effects of AGE Breakers}

AGE breakers, a new class of candidate drugs targeting ageing-related cardiovascular dysfunction, may be useful as novel adjuvant agents to improve the efficacy of diabetic hypertension treatment. Experiments conducted by Zhang et al. (2014) demonstrated that 4,5-dimethyl-3-phenacylthiozolium chloride (alagebrium, ALT-711) significantly improves the anti-hypertensive actions of nifedipine, a $\mathrm{Ca}^{2+}$ channel blocker, in a rat model of streptozotocin-induced diabetic hypertension [113]. Freidja et al. (2014) reported that ALT-711 did not improve flow-mediated remodeling of resistance arteries in mature Zucker Diabetic Fatty rats but it reduced oxidative stress and consequently improved endothelium-dependent relaxation. On the other hand, in mature lean Zucker rats, ALT-711 improved flow-mediated remodeling of resistance arteries and reduced AGEs level. Thus, AGEs breaking, at least using ALT-711, could be a useful therapeutic tool in ameliorating diabetic complications and with the capacity to improve flow-mediated remodeling in non-diabetic subjects [114]. AGEs breaking and antioxidant treatment improves endothelium-dependent dilation without effect on flow-mediated remodeling of resistance arteries in old Zucker diabetic rats. Sakul et al. (2013) applied 2-ethoxycarbonyl-8-methoxy2,3,4,4a,5,9b-hexahydro-1H-pyrido[4,3-b]indolinium dichloride (SMe1EC2) treatment during 4 months to aged streptozotocin-diabetic rats. They demonstrated that AGEs and 4-hydroxy-nonenal-histidine levels is significantly elevated in brain, ventricle and kidney, but not in lens and liver of aged rats when compared with young rats. In aged diabetic rats, SMe1EC2 protected only the kidney against increase in AGEs. However, it is not certain whether any natural compounds can act as AGE breakers [115]. 
Table 1. Results of chosen in vivo studies of the effects of natural compounds on glycation.

\begin{tabular}{|c|c|c|c|}
\hline Population & Intervention & Main Findings & Reference \\
\hline $\begin{array}{l}\text { Healthy male Sprague-Dawley } \\
\text { rats }(220 \pm 20 \mathrm{~g} \text { ) were divided } \\
\text { randomly into four groups each } \\
\text { containing } 10 \text { rats: control group, } \\
\text { fructose group, betanin } 25 \mathrm{mg} / \mathrm{kg} \\
\text { per day group, and betanin } \\
100 \mathrm{mg} / \mathrm{kg} \text { per day group. }\end{array}$ & $\begin{array}{l}\text { Fructose water solution }(30 \%) \text { was accessed freely, and } \\
\text { betanin (betanidin } 5-O-\beta \text {-D-glucoside, red) }(25 \text { and } \\
100 \mathrm{mg} / \mathrm{kg} / \mathrm{d}) \text { was administered by intra-gastric gavage } \\
\text { continuously for } 60 \text { days. }\end{array}$ & $\begin{array}{l}\text { Betanin decreased protein glycation indexed by the } \\
\text { relative lower methylglyoxal/ N-carboxymethyl lysine } \\
\text { (CML) level and RAGE expression, and reduced } \\
\text { glycative products in BSA/fructose system. Betanin } \\
\text { also antagonized oxidative stress and NF-kB } \\
\text { activation, all of them may be involved in the } \\
\text { antifibrotic mechanisms. Food pigments may } \\
\text { neutralize adverse effects of carbohydrate, i.e., diabetes } \\
\text { and related syndrome, and complementary therapy } \\
\text { with betanin may prove useful in attenuating the } \\
\text { development of cardiac fibrosis in diabetes. }\end{array}$ & [116] \\
\hline $\begin{array}{l}\text { Male C57 BLKS/J genetic } \\
\text { background }(d b / d b) \text { mice and their } \\
\text { non-diabetic lean littermates } \\
\text { ( } d b / m ; 6 \text {-wk-old)were randomly } \\
\text { divided into five groups ( } n=8 \\
\text { each). }\end{array}$ & $\begin{array}{l}\text { Mice were orally administered vehicle (sterile distilled } \\
\text { water), metformin }(300 \mathrm{mg} / \mathrm{kg}) \text {, and }(+) \text {-catechin }(15,30 \text {, } \\
\text { and } 60 \mathrm{mg} / \mathrm{kg} \text { fresh preparation with sterile distilled } \\
\text { water) daily at } 4: 00 \mathrm{pm} \text {, continuously for } 16 \text { weeks. } \\
\text { Metformin was used as a positive antidiabetic drug, and } \\
\mathrm{db} / \mathrm{m} \text { mice were used as non-diabetic controls. After } \\
4-6 \mathrm{~h} \text { fasting at the end of the treatment period, mice } \\
\text { were killed and kidney tissues were saved for further } \\
\text { assays. }\end{array}$ & $\begin{array}{l}(+) \text {-Catechin might ameliorate renal dysfunction in } \\
\text { diabetic mice as consequences of inhibiting AGEs } \\
\text { formation and cutting off inflammatory pathway via } \\
\text { methylglyoxal trapping. }\end{array}$ & [117] \\
\hline
\end{tabular}


Table 1. Cont

\begin{tabular}{|c|c|c|c|}
\hline Population & Intervention & Main Findings & Reference \\
\hline $\begin{array}{l}\text { Two-month-old male Wistar NIN } \\
\text { rats with an average bodyweight of } \\
220 \pm 17 \text { g were used in the study. } \\
\text { Animals were distributed into four } \\
\text { groups (groups I-IV). Each group } \\
\text { consists of six animals. }\end{array}$ & $\begin{array}{l}\text { All the animals were fed with AIN-93 diet ad libitum. } \\
\text { The control (group I) rats received sham consists of } \\
0.1 \mathrm{M} \text { citrate buffer, pH } 4.5 \text { while the experimental rats } \\
\text { received a single i.p injection of streptozotocin (STZ, } \\
35 \mathrm{mg} / \mathrm{kg} \text { ) in citrate buffer. Animals in group II received } \\
\text { AIN-93 diet alone whereas group III animals received } \\
\text { the AIN-93 diet supplemented with } 3 \% \text { cinnamon } \\
\text { powder whereas group IV animals received AIN-93 diet } \\
\text { containing } 0.002 \% \text { procyanidin-B2 -fraction. All the } \\
\text { animals had free access to water. }\end{array}$ & $\begin{array}{l}\text { Supplementation of diabetic rats with cinnamon and } \\
\text { procyanidin-B2 -fraction prevented glycation mediated } \\
\text { RBC-IgG cross-links and HbA1c accumulation in } \\
\text { diabetes rats. Cinnamon and procyanidin-B2 -fraction } \\
\text { also inhibited the accumulation of CML, a prominent } \\
\text { AGE in diabetic kidney. Cinnamon and its } \\
\text { procyanidin-B2 -fraction prevented the AGE mediated } \\
\text { loss of expression of glomerular podocyte proteins; } \\
\text { nephrin and podocin. Inhibition of AGE by cinnamon } \\
\text { and procyanidin-B2 -fraction ameliorated the diabetes } \\
\text { mediated renal malfunction in rats as evidenced by } \\
\text { reduced urinary albumin and creatinine. Procyanidin- } \\
\text { B2 from cinnamon inhibited AGE accumulation in } \\
\text { diabetic rat kidney and ameliorated AGE mediated } \\
\text { pathogenesis of diabetic nephropathy. }\end{array}$ & [118] \\
\hline $\begin{array}{l}\text { Male Wistar rats }(200-230 \mathrm{~g}) \text { were } \\
\text { obtained from Sanzyme Ltd. } \\
\text { (Hyderabad, India). The animals } \\
\text { were divided into } 4 \text { groups }(n=8) \text {. }\end{array}$ & $\begin{array}{l}\text { Diabetes was induced in all the male Wistar rats } \\
\text { ( } 200-250 \text { g) except a group of eight animals which were } \\
\text { treated as naïve (group I) by intraperitoneal } \\
\text { administration of STZ ( } 45 \mathrm{mg} / \mathrm{kg} \text { ) dissolved in freshly } \\
\text { prepared citrate buffer ( } \mathrm{pH} 4.5 \text { ). The animals were fasted } \\
\text { for } 12 \mathrm{~h} \text { before STZ administration and supplemented } \\
\text { with } 10 \% \text { glucose for } 48 \mathrm{~h} \text { after STZ administration. One } \\
\text { week after streptozotocin administration, blood glucose } \\
\text { was estimated and the animals with more than } 300 \\
\text { mg/dL were treated as diabetic and after a period of } 6 \\
\text { weeks, the animals were divided into } 3 \text { groups. Group II } \\
\text { served as diabetic control where as group III and group } \\
\text { IV received resveratrol ( } 10 \mathrm{mg} / \mathrm{kg} \text { ) and fidarestat } \\
(1 \mathrm{mg} / \mathrm{kg} \text { ), by per oral administration respectively, for a } \\
\text { period of } 3 \text { weeks. }\end{array}$ & $\begin{array}{l}\text { Resveratrol significantly improved glycaemic status } \\
\text { and renal function in diabetic rats with a significant } \\
\text { decrease in the formation of AGEs in the kidneys. }\end{array}$ & [119] \\
\hline
\end{tabular}


Table 1. Cont

\begin{tabular}{|c|c|c|c|}
\hline Population & Intervention & Main Findings & Reference \\
\hline $\begin{array}{l}\text { Male Wistar rats (initial weight of } \\
50-75 \mathrm{~g} \text { ) were obtained from } \\
\text { Charles River Breeding } \\
\text { Laboratories (St-Constant, Qc, } \\
\text { Canada). The animals were divided } \\
\text { into six groups }\left(\mathrm{Ctr}_{3}, n=10 ; \mathrm{D}_{3} \text {, }\right. \\
n=8 ; \mathrm{PYR}, n=8 ; \mathrm{Ctrl}_{7}, n=9 ; \mathrm{D}_{7}, \\
n=8 ; \mathrm{ALA}, n=7)\end{array}$ & 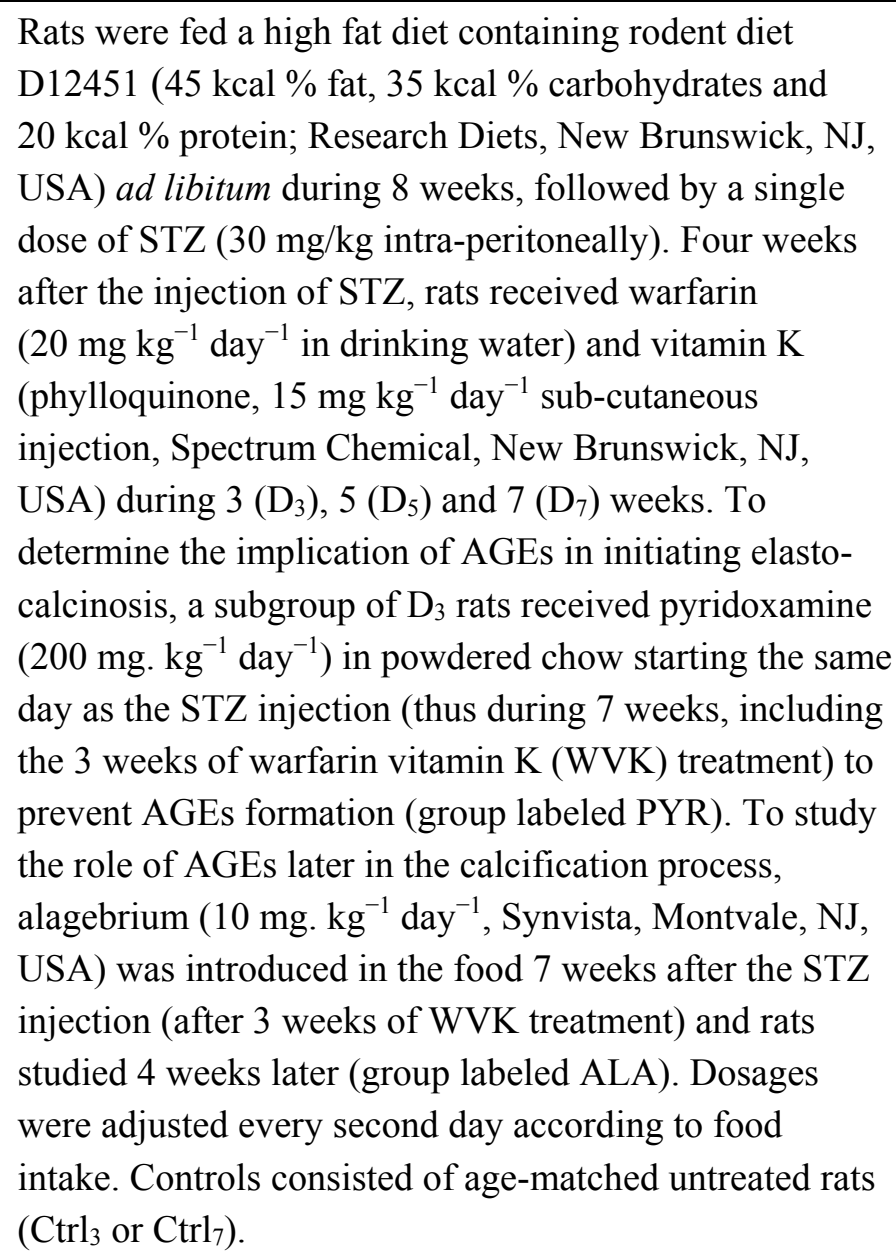 & $\begin{array}{l}\text { Pyridoxamine (PYR) prevented AGE accumulation, } \\
\text { whereas alagebrium chloride (ALT-711) induced a } \\
\text { regression of AGE cross-links. PYR prevented calcium } \\
\text { accumulation, while alagebrium blunted the } \\
\text { progression of calcification. }\end{array}$ & {$[120]$} \\
\hline
\end{tabular}


Table 1. Cont

\begin{tabular}{|c|c|c|c|}
\hline Population & Intervention & Main Findings & Reference \\
\hline $\begin{array}{l}\text { Sprague Dawley (SD) rats were } \\
\text { divided into five groups } \\
(n=9 \text { each). }\end{array}$ & $\begin{array}{l}\text { Diabetes was induced by a single injection of } \\
\text { streptozotocin (STZ, } 60 \mathrm{mg} / \mathrm{kg} \text {, intraperitoneally) in rats. } \\
\text { Age-matched control rats (aged } 6 \text { weeks) received an } \\
\text { equal volume of vehicle ( } 0.01 \mathrm{M} \text { citrate buffer, } \mathrm{pH} 4.5) \text {. } \\
\text { To investigate the effects of Cassiae semen (CS) extract, } \\
\text { treatment was begun one week after the onset of diabetes } \\
\text { and the compound was orally administered to the rats } \\
\text { once a day for } 12 \text { weeks. SD rats were divided into } \\
\text { groups: (1) normal rats }(\mathrm{N}),(2) \text { normal rats treated with } \\
\text { CS (N + CS), (3) STZ-induced diabetic rats (DM), (4) } \\
\text { STZ-induced diabetic rats treated with CS (DM + CS, } \\
100 \mathrm{mg} / \mathrm{kg} \text { body weight), and (5) STZ-induced diabetic } \\
\text { rats treated with aminoguanidine (AG), a positive control } \\
\text { for AGEs inhibitor (DM + AG, } 100 \mathrm{mg} / \mathrm{kg} \text { body weight). }\end{array}$ & $\begin{array}{l}\text { Oral treatment of CS can inhibit the development of } \\
\text { diabetic nephropathy via inhibition of AGEs } \\
\text { accumulation in STZ-induced diabetic rats } \\
\text { The CS-treated group had significantly inhibited } \\
\text { COX-2 mRNA and protein, which mediates the } \\
\text { symptoms of inflammation in the renal cortex of } \\
\text { diabetic rats. Histopathological studies of kidney tissue } \\
\text { showed that in diabetic rats, AGEs, the receptor for } \\
\text { AGEs, TGF- } \beta 1 \text {, and collagen IV were suppressed by } \\
\text { CS treatment. }\end{array}$ & {$[121]$} \\
\hline $\begin{array}{l}\text { In vivo experiments were } \\
\text { performed on 6-week-old male } \\
\text { Wistar albino rats weighing } \\
\text { 180-200 g. The animals were } \\
\text { divided into } 12 \text { groups, each } \\
\text { containing six animals, and each } \\
\text { test sample was given to two } \\
\text { groups of rats. }\end{array}$ & $\begin{array}{l}\text { The control and all test groups were orally fed with } \\
\text { galactose at a dose of } 10 \mathrm{mg} / \mathrm{kg} \text { body weight. Boswellic } \\
\text { acid, corsolic acid, ellagic acid ursolic acid and quercetin } \\
\text { were given at a dose of } 10 \mathrm{mg} / \mathrm{kg} \text { body weight. All the } \\
\text { animals were sacrificed on the } 15 \text { th day by spinal } \\
\text { nerve dislocation. }\end{array}$ & $\begin{array}{l}\text { All the tested extracts and their active ingredients } \\
\text { possess significant the polyol enzyme aldose reductase } \\
\text { inhibitory actions with urosolic acid showing the most } \\
\text { potent effect. The study indicates the potential of the } \\
\text { studied plants and their major constituents as possible } \\
\text { protective agents against long-term } \\
\text { diabetic complications. }\end{array}$ & {$[122]$} \\
\hline
\end{tabular}


Table 1. Cont.

\begin{tabular}{|c|c|c|c|}
\hline Population & Intervention & Main Findings & Reference \\
\hline $\begin{array}{l}\text { A total of } 48 \text { male Kunming mice } \\
\text { were used (four groups, } 12 \text { mice in } \\
\text { each group). }\end{array}$ & $\begin{array}{l}\text { The aggregated } \mathrm{A} \beta_{25-35} \text { was injected into the right lateral } \\
\text { ventricle with the following coordinates: }-0.5 \mathrm{~mm} \\
\text { anterior/posterior, }+1.0 \mathrm{~mm} \text { medial } / \text { lateral and }-2.5 \mathrm{~mm} \\
\text { dorsal/ventral from Bregma ( } 10 \mathrm{nmol} \text { in } 3 \mu \mathrm{L} \text { of saline } \\
\text { per injection). Sham animals were injected in an } \\
\text { identical manner with the same amount of sterile saline. } \\
\text { Mice were allocated to one of four groups the day after } \\
\text { sterile saline or } \mathrm{A} \beta_{25-35} \text { injection: sham group, } \\
\mathrm{A} \beta_{25-35} \text {-treated group, pinocembrin } 20 \mathrm{mg} / \mathrm{kg} \text { group, and } \\
\text { pinocembrin } 40 \mathrm{mg} / \mathrm{kg} \text { group. Pinocembrin was } \\
\text { administered by oral gavage once a day continuously for } \\
8 \text { days. The sham group and A } \beta_{25-35} \text {-treated group } \\
\text { received oral gavage in the same manner using distilled } \\
\text { water containing } 20 \% \text { hydroxypropyl- } \beta \text {-cyclodextrin } \\
\text { without pinocembrin. }\end{array}$ & $\begin{array}{l}\text { Pinocembrin (a flavonoid abundant in propolis), } \\
\text { significantly inhibited the upregulation of RAGE } \\
\text { transcripts and protein expression both in vivo and } \\
\text { in vitro, and also markedly depressed the activation of } \\
\text { p38 mitogen-activated protein kinase } \\
\text { (MAPK)-MAPKAP kinase-2 (MK2)-heat shock } \\
\text { protein } 27 \text { (HSP27) and stress-activated protein kinase } \\
\text { (SAPK)/c-Jun N-terminal kinase (JNK)-c-Jun } \\
\text { pathways and the downstream nuclear factor } \kappa \mathrm{B} \\
\text { (NFKB) inflammatory response subsequent to } \\
\text { A } \beta \text {-RAGE interaction. } \\
\text { Pinocembrin significantly alleviated mitochondrial } \\
\text { dysfunction through improving mitochondrial } \\
\text { membrane potential and inhibiting mitochondrial } \\
\text { oxidative stress, and regulated mitochondrion-mediated } \\
\text { apoptosis by restoration of B cell lymphoma } 2 \text { (Bcl-2) } \\
\text { and cytochrome } c \text { and inactivation of caspase } 3 \text { and } \\
\text { caspase } 9 \text {. }\end{array}$ & {$[123]$} \\
\hline $\begin{array}{l}\text { Zebrafish maintenance and } \\
\text { experimental procedures were } \\
\text { approved by the Committee of } \\
\text { Animal Care and Use of } \\
\text { Yeungnam University } \\
\text { (Gyeongsan, South Korea). Each } \\
\text { group ( } n=70) \text { consumed the } \\
\text { designated diet ( } 20 \mathrm{mg} / \text { day/fish). }\end{array}$ & $\begin{array}{l}\text { A high cholesterol (HC) diet containing } 4 \% \text { cholesterol } \\
\text { was made by soaking tetrabit [Tetrabit Gmbh D } 49304 \text {; } \\
47.5 \% \text { crude protein, } 6.5 \% \text { crude fat, } 2.0 \% \text { crude fiber, } \\
10.5 \% \text { crude ash, containing vitamin A }(29,770 \mathrm{IU} / \mathrm{kg}) \text {, } \\
\text { vitamin D3 ( } 1860 \mathrm{IU} / \mathrm{kg}) \text {, vitamin E }(200 \mathrm{mg} / \mathrm{kg}) \text {, and } \\
\text { vitamin C ( } 137 \mathrm{mg} / \mathrm{kg}) \text {; (Melle, Germany)] in a solution } \\
\text { of cholesterol in diethyl ether. After ether evaporation, } \\
\text { HC diet was mixed with lyophilized fruit extract (a final } \\
\text { concentration of } 10 \% \text { w/w of powder/ tetrabit). The } \\
\text { animals were divided into } 5 \text { groups: normal diet (ND) } \\
\text { group, high cholesterol (HC) diet group, HC + LL } \\
\text { (loquat leaves) group, acai-fed group (HC + acai) and } \\
\text { HC + GS (grape skin) group. }\end{array}$ & $\begin{array}{l}\text { Serum glucose levels increased in the high cholesterol } \\
\text { diet group, to threefold above the ND group; GS and } \\
\text { LL feeding elicited the greatest reduction in } \\
\text { hyperglycemia. The groups consuming acai and LL } \\
\text { showed much less hepatic inflammation, as well as } \\
\text { attenuation of fatty liver and a reduced content of } \\
\text { oxidized species. }\end{array}$ & [124] \\
\hline
\end{tabular}


Table 1. Cont

\begin{tabular}{|c|c|c|c|}
\hline Population & Intervention & Main Findings & Reference \\
\hline $\begin{array}{l}\text { A total of } 15 \text { male inbred C } 57 \mathrm{BL} / 6 \\
\mathrm{~J} \text { mice were used ( } 3 \text { groups, } 5 \text { mice } \\
\text { in each group). }\end{array}$ & $\begin{array}{l}\text { Diabetes was induced in the mice by a single dose of } \\
\text { STZ ( } 200 \mathrm{mg} / \mathrm{kg}) \text {. Mice were fed a normal rodent chow } \\
\text { diet (Clea Japan) for } 1 \text { week after induction of diabetes. } \\
\text { At this time, these mice were administered epicatechin } \\
\text { ( } 500 \mathrm{mg} / \mathrm{kg} / \text { day) orally every day for } 45 \text { days. Animals } \\
\text { were divided into groups: control group, mice treated } \\
\text { with epicatechin ( } 500 \mathrm{mg} / \mathrm{kg} / \mathrm{day}) \text {, and mice treated with } \\
\text { arbutin, a catechol analogue }(500 \mathrm{mg} / \mathrm{kg} / \text { day). }\end{array}$ & $\begin{array}{l}\text { Administration of } 500 \mathrm{mg} / \mathrm{kg} / \text { day epicatechin to STZ- } \\
\text { induced diabetic mice enhanced the CML } \\
\text { accumulation on the surface of gastric epithelial cells, } \\
\text { whereas administration of } 500 \mathrm{mg} / \mathrm{kg} / \text { day arbutin to } \\
\text { STZ-induced diabetic mice did not enhance CML } \\
\text { accumulation compared to untreated mice. High } \\
\text { amounts of catechol-containing structures enhance } \\
\text { oxidative stress, thus leading to enhanced CML } \\
\text { formation, and this phenomenon may explain the } \\
\text { paradoxical effect that some flavonoids have on redox } \\
\text { status. }\end{array}$ & [111] \\
\hline $\begin{array}{l}\text { Adult male Wistar rats of body } \\
\text { weight } 150-160 \mathrm{~g} \text { were used in the } \\
\text { study. The animals were divided } \\
\text { into four groups of six rats each. }\end{array}$ & $\begin{array}{l}\text { Control animals (CON) received the control diet } \\
\text { containing starch and tap water ad libitum. Fructose-fed } \\
\text { animals (FRU) received the high fructose diet and water } \\
\text { ad libitum. Fructose-fed animals (FRU-CA) received the } \\
\text { high fructose diet and water ad libitum and were } \\
\text { administered } 300 \mathrm{mg} \text { carnitine (CA)/kg b.w/day; i.p. } \\
\text { Control animals (CON-CA) received the control diet and } \\
\text { water ad libitum and were administered with } 300 \mathrm{mg} \\
\text { CA/kg b.w/day; i.p. }\end{array}$ & $\begin{array}{l}\text { The levels of glucose, fructose and fructosamine in } \\
\text { plasma and glycated haemoglobin and methyl glyoxal } \\
\text { in blood were significantly higher in fructose-fed } \\
\text { animals than in the control rats. Administration of CA } \\
\text { along with the fructose diet reduced these levels } \\
\text { significantly. In rats fed control diet, administration of } \\
\text { CA did not produce significant alterations in the } \\
\text { parameters when compared with the control group. The } \\
\text { rats fed fructose diet showed increased total collagen } \\
\text { and glycation in tail tendon and skin as compared to } \\
\text { control rats. CA-administered fructose-fed rats } \\
\text { registered near-normal levels of collagen and } \\
\text { glycation. No significant changes were observed in } \\
\text { control rats treated with CA. }\end{array}$ & [84] \\
\hline
\end{tabular}




\section{Conclusions}

Many natural compounds, especially polyphenols, have been found to inhibit efficiently protein glycation in vitro. Their action in vivo is more problematic due to the bioavailability problems. Nevertheless, some positive effects of natural antioxidants against the consequences of excessive glycation have been found. While the mechanisms of their action may go beyond direct inhibition of glycation, there are reasons to expect that natural compounds used as food additives may prevent adverse effects of protein glycation and, in consequence, delay ageing. Another useful approach may consist in limitation of AGE intake in the food.

\section{Acknowledgments}

This paper is a result of our involvement in the COST CM1001 Action "Chemistry of non-enzymatic protein modification - modulation of protein structure and function" and Project COST 2011/01/M/N2302065 "Prevention of posttranslational protein modifications" (National Science Centre, Poland).

\section{Author Contributions}

I.S.-B. made the literature search and prepared the manuscript. G.B. participated in the edition of the final version of the manuscript.

\section{Conflicts of Interest}

The authors declare no conflict of interest.

\section{References}

1. Maillard, L.C. Action des acides aminés sur les sucres: Formation des mélanoidines par voie méthodique. Réaction de Maillard. C. R. Acad. Sci. 1912, 154, 66-68.

2. Severin, F.F.; Feniouk, B.A.; Skulachev, V.P. Advanced glycation of cellular proteins as a possible basic component of the "master biological clock". Biochemistry (Mosc.) 2013, 78, 1043-1047.

3. Vistoli, G.; de Maddis, D.; Cipak, A.; Zarkovic, N.; Carini, M.; Aldini, G. Advanced glycoxidation and lipoxidation end products (AGEs and ALEs): An overview of their mechanisms of formation. Free Radic. Res. 2013, 47 (Suppl. 1), 3-27.

4. Ahmed, N. Advanced glycation endproducts-role in pathology of diabetic complications. Diabetes Res. Clin. Pract. 2005, 67, 3-21.

5. Sell, D.R.; Monnier, V.M. Isolation, purification and partial characterization of novel fluorophores from aging human insoluble collagen-rich tissue. Connect. Tissue Res. 1989, 19, 77-92.

6. Monnier, V.M.; Sell, D.R.; Strauch, C.; Sun, W.; Lachin, J.M.; Cleary, P.A.; Genuth, S. The association between skin collagen glucosepane and past progression of microvascular and neuropathic complications in type 1 diabetes. J. Diabetes Complicat. 2013, 27, 141-149.

7. Thorpe, S.R.; Baynes, J.W. Maillard reaction products in tissue proteins: New products and new perspectives. Amino Acids 2003, 25, 275-281. 
8. Peppa, M.; Uribarri, J.; Vlassara, H. Aging and glycoxidant stress. Hormones (Athens) 2008, 7, $123-132$.

9. Rondeau, P.; Navarra, G.; Cacciabaudo, F.; Leone, M.; Bourdon, E.; Militello, V. Thermal aggregation of glycated bovine serum albumin. Biochim. Biophys. Acta 2010; 1804, 789-798.

10. Rondeau, P.; Bourdon, E. The glycation of albumin: Structural and functional impacts. Biochimie 2011, 93, 645-658.

11. Muthenna, P.; Akileshwari, C.; Saraswat, M.; Bhanuprakash Reddy, G. Inhibition of advanced glycation end-product formation on eye lens protein by rutin. Br. J. Nutr. 2012, 107, 941-949.

12. Aldini, G.; Vistoli, G.; Stefek, M.; Chondrogianni, N.; Grune, T.; Sereikaite, J.; Sadowska-Bartosz, I.; Bartosz, G. Molecular strategies to prevent; inhibit; and degrade advanced glycoxidation and advanced lipoxidation end products. Free Radic. Res. 2013, 47 (Suppl. 1), 93-137.

13. Krautwald, M.; Münch, G. Advanced glycation end products as biomarkers and gerontotoxins-A basis to explore methylglyoxal-lowering agents for Alzheimer's disease? Exp. Gerontol. 2010, 45, $744-751$.

14. Giardino, I.; Edelstein, D.; Brownlee, M. Nonenzymatic glycosylation in vitro and in bovine endothelial cells alters basic fibroblast growth factor activity. A model for intracellular glycosylation in diabetes. J. Clin. Investig. 1994, 94, 110-117.

15. Brownlee, M. Biochemistry and molecular cell biology of diabetic complications. Nature 2001, 414, 813-820.

16. Uchiki, T.; Weikel, K.A.; Jiao, W.; Shang, F.; Caceres, A.; Pawlak, D.; Handa, J.T.; Brownlee, M.; Nagaraj, R.; Taylor, A. Glycation-altered proteolysis as a pathobiologic mechanism that links dietary glycemic index, aging, and age-related disease (in nondiabetics). Aging Cell 2012, 11, 1-13.

17. Goh, S.Y.; Cooper, M.E. Clinical review: The role of advanced glycation end products in progression and complications of diabetes. J. Clin. Endocrinol. Metab. 2008, 93, 1143-1152.

18. Brownlee, M. Advanced protein glycosylation in diabetes and aging. Annu. Rev. Med. 1995, 46, 223-234.

19. Cooper, M.E.; Bonnet, F.; Oldfield, M.; Jandeleit-Dahm, K. Mechanisms of diabetic vasculopathy: An overview. Am. J. Hypertens. 2001, 14, 475-486.

20. Yuen, A.; Laschinger, C.; Talior, I.; Lee, W.; Chan, M.; Birek, J.; Young, E.W.; Sivagurunathan, K.; Won, E.; Simmons, C.A.; et al. Methylglyoxal-modified collagen promotes myofibroblast differentiation. Matrix Biol. 2010, 29, 537-548.

21. Kemeny, S.F.; Figueroa, D.S.; Andrews, A.M.; Barbee, K.A.; Clyne, A.M. Glycated collagen alters endothelial cell actin alignment and nitric oxide release in response to fluid shear stress. J. Biomech. 2011, 44, 1927-1935.

22. Hanssen, N.M.; Wouters, K.; Huijberts, M.S.; Gijbels, M.J.; Sluimer, J.C.; Scheijen, J.L.; Heeneman, S.; Biessen, E.A.; Daemen, M.J.; Brownlee, M.; et al. Higher levels of advanced glycation endproducts in human carotid atherosclerotic plaques are associated with a rupture-prone phenotype. Eur. Heart J. 2014, 35, 1137-1146.

23. Ramasamy, R.; Yan, S.F.; Schmidt, A.M. The diverse ligand repertoire of the receptor for advanced glycation endproducts and pathways to the complications of diabetes. Vasc. Pharmacol. 2012, 57, 160-167. 
24. Marinakis, E.; Bagkos, G.; Piperi, C.; Roussou, P.; Diamanti-Kandarakis, E. Critical role of RAGE in lung physiology and tumorigenesis: A potential target of therapeutic intervention? Clin. Chem. Lab. Med. 2014, 52, 189-200.

25. Merhi, Z. Advanced glycation end products and their relevance in female reproduction. Hum. Reprod. 2014, 29, 135-145.

26. Sadowska-Bartosz, I.; Galiniak, S.; Bartosz, G.; Rachel, M. Oxidative modification of proteins in pediatric cystic fibrosis with bacterial infections. Oxid. Med. Cell. Longev. 2014, 2014, 389629.

27. Kan, H.; Yamagishi, S.I.; Ojima, A.; Fukami, K.; Ueda, S.; Takeuchi, M.; Hyogo, H.; Aikata, H.; Chayama, K. Elevation of serum levels of advanced glycation end products in patients with non-B or non-C hepatocellular carcinoma. J. Clin. Lab. Anal. 2014, doi:10.1002/jcla.21797.

28. Sadowska-Bartosz, I.; Adamczyk-Sowa, M.; Galiniak, S.; Mucha, S.; Pierzchala, K.; Bartosz, G. Oxidative modification of serum proteins in multiple sclerosis. Neurochem. Int. 2013, 63, $507-516$.

29. Sadowska-Bartosz, I.; Adamczyk-Sowa, M.; Gajewska, A.; Bartosz, G. Oxidative modification of blood serum proteins in multiple sclerosis after interferon or mitoxantrone treatment. J. Neuroimmunol. 2014, 266, 67-74.

30. Miyashita, M.; Arai, M.; Kobori, A.; Ichikawa, T.; Toriumi, K.; Niizato, K.; Oshima, K.; Okazaki, Y.; Yoshikawa, T.; Amano, N.; et al. Clinical features of schizophrenia with enhanced carbonyl stress. Schizophr. Bull. 2014, 40, 1040-1046.

31. Bouma, B.; Kroon-Batenburg, L.M.; Wu, Y.P.; Brünjes, B.; Kranenburg, O.; de Groot, P.G.; Voest, E.E.; Gebbink, M.F. Glycation induces formation of amyloid cross-beta structure in albumin. J. Biol. Chem. 2003, 278, 41810-41819.

32. Salahuddin, P.; Rabbani, G.; Khan, R.H. The role of advanced glycation end products in various types of neurodegenerative disease, a therapeutic approach. Cell. Mol. Biol. Lett. 2014, 19, 407-437.

33. Thome, J.; Münch, G.; Müller, R.; Schinzel, R.; Kornhuber, J.; Blum-Degen, D.; Sitzmann, L.; Rösler, M.; Heidland, A.; Riederer, P. Advanced glycation end products-associated parameters in the peripheral blood of patients with Alzheimer's disease. Life Sci. 1996, 59, 679-685.

34. Riviere, S.; Birlouez-Aragon, I.; Vellas, B. Plasma protein glycation in Alzheimer's disease. Glycoconj. J. 1998, 15, 1039-1042.

35. Leszek, J.; Malyszczak, K.; Bartys, A.; Staniszewska, M.; Gamian, A. Analysis of serum of patients with Alzheimer's disease for the level of advanced glycation end products. Am. J. Alzheimers Dis. Other Demen. 2006, 21, 360-365.

36. Harding, J.J.; Egerton, M.; van Heyningen, R.; Harding, R.S. Diabetes, glaucoma, sex, and cataract, analysis of combined data from two case control studies. Br. J. Ophthalmol. 1993, 77, $2-6$.

37. Nagaraj, R.H.; Linetsky, M.; Stitt, A.W. The pathogenic role of Maillard reaction in the aging eye. Amino Acids 2012, 42, 1205-1220.

38. Kumar, M.S.; Reddy, P.Y.; Kumar, P.A.; Surolia, I.; Reddy, G.B. Effect of dicarbonyl-induced browning on alpha-crystallin chaperone-like activity: Physiological significance and caveats of in vitro aggregation assays. Biochem. J. 2004, 379 (Pt 2), 273-282. 
39. Stitt, A.W.; Curtis, T.M. Diabetes-related adduct formation and retinopathy. J. Ocul. Biol. Dis. Inform. 2011, 4, 10-18.

40. Berner, A.K.; Brouwers, O.; Pringle, R.; Klaassen, I.; Colhoun, L.; McVicar, C.; Brockbank, S.; Curry, J.W.; Miyata, T.; Brownlee, M.; et al. Protection against methylglyoxal-derived AGEs by regulation of glyoxalase 1 prevents retinal neuroglial and vasodegenerative pathology. Diabetologia 2012, 55, 845-854

41. Nowotny, K.; Jung, T.; Grune, T.; Höhn, A. Accumulation of modified proteins and aggregate formation in aging. Exp. Gerontol. 2014, 57C, 122-131.

42. Monnier, V.M.; Stevens, V.J.; Cerami, A. Maillard reactions involving proteins and carbohydrates in vivo: Relevance to diabetes mellitus and aging. Prog. Food Nutr. Sci. 1981, 5, 315-327.

43. Ichihashi, M.; Yagi, M.; Nomoto, K.; Yonei, Y. Glycation stress and photo-aging in skin. Anti-Aging Med. 2011, 8, 23-29.

44. Beppu, M.; Inoue, M.; Ishikawa, T.; Kikugawa, K. Presence of membrane bound proteinases that preferentially degrade oxidatively damaged erythrocyte membrane proteins as secondary antioxidant defense. Biochim. Biophys. Acta 1994, 1196, 81-87.

45. Lee, D.Y.; Chang, G.D. Methylglyoxal in cells elicits a negative feedback loop entailing transglutaminase 2 and glyoxalase 1. Redox Biol. 2014, 2, 196-205.

46. Kuhla, A.; Ludwig, S.C.; Kuhla, B.; Münch, G.; Vollmar, B. Advanced glycation end products are mitogenic signals and trigger cell cycle reentry of neurons in Alzheimer's disease brain. Neurobiol. Aging 2014, doi:10.1016/j.neurobiolaging.2014.09.025.

47. Dworkin, J.P.; Miller, S.L. A kinetic estimate of the free aldehyde content of aldoses. Carbohydr. Res. 2000, 329, 359-365.

48. Lu, J.; Wu, D.M.; Zheng, Y.L.; Hu, B.; Zhang, Z.F. Purple sweet potato color alleviates D-galactose-induced brain aging in old mice by promoting survival of neurons via PI3K pathway and inhibiting cytochrome C-mediated apoptosis. Brain Pathol. 2010, 20, 598-612.

49. Mao, G.X.; Deng, H.B.; Yuan, L.G.; Li, D.D.; Li, Y.Y.; Wang, Z. Protective role of salidroside against aging in a mouse model induced by D-galactose. Biomed. Environ. Sci. 2010, 23, 161-166.

50. Wang, P.-C.; Zhang, J.; Zhang, Z.-Y.; Tong, T.-J. Aminoguanidine delays the replicative senescence of human diploid fibroblasts. Chin. Med. J. 2007, 120, 2028-2035.

51. Van Puyvelde, K.; Mets, T.; Njemini, R.; Beyer, I.; Bautmans, I. Effect of advanced glycation end product intake on inflammation and aging: A systematic review. Nutr. Rev. 2014, 72, 638-650.

52. Nagai, R.; Shirakawa, J.; Fujiwara, Y.; Ohno, R.; Moroishi, N.; Sakata, N.; Nagai, M. Detection of AGEs as markers for carbohydrate metabolism and protein metabolism. J. Clin. Biochem. Nutr. 2014, 55, 1-6.

53. Desai, K.; Wu, L. Methylglyoxal and advanced glycation endproducts: New therapeutic horizons? Recent Pat. Cardiovasc. Drug Discov. 2007, 2, 89-99.

54. Thornalley, P.J. Use of aminoguanidine (Pimagedine) to prevent the formation of advanced glycation endproducts. Arch. Biochem. Biophys. 2003, 419, 31-40.

55. Nagai, R.; Murray, D.B.; Metz, T.O.; Baynes, J.W. Chelation, a fundamental mechanism of action of AGE inhibitors, AGE breakers, and other inhibitors of diabetes complications. Diabetes 2012, $61,549-559$. 
56. Voziyan, P.A.; Hudson, B.G. Pyridoxamine as a multifunctional pharmaceutical: Targeting pathogenic glycation and oxidative damage. Cell. Mol. Life Sci. 2005, 62, 1671-1681.

57. Degenhardt, T.P.; Alderson, N.L.; Arrington, D.D.; Beattie, R.J.; Basgen, J.M.; Steffes, M.W.; Thorpe, S.R.; Baynes, J.W. Pyridoxamine inhibits early renal disease and dyslipidemia in the streptozotocin-diabetic rat. Kidney Int. 2002, 61, 939-950.

58. Balakumar, P.; Rohilla, A.; Krishan, P.; Solairaj, P.; Thangathirupathi, A. The multifaceted therapeutic potential of benfotiamine. Pharmacol. Res. 2010, 61, 482-488.

59. Wells-Knecht, K.J.; Brinkmann, E.; Wells-Knecht, M.C.; Litchfield, J.E.; Ahmed, M.U.; Reddy, S.; Zyzak, D.V.; Thorpe, S.R.; Baynes, J.W. New biomarkers of Maillard reaction damage to proteins. Nephrol. Dial. Transplant. 1996, 11 (Suppl. 5), 41-47.

60. Khalifah, R.G.; Baynes, J.W.; Hudson, B.G. Amadorins: Novel post-Amadori inhibitors of advanced glycation reactions. Biochem. Biophys. Res. Commun. 1999, 257, 251-258.

61. Ahmad, H.; Khan, I.; Wahid, A. Antiglycation and antioxidation properties of Juglans regia and Calendula officinalis: Possible role in reducing diabetic complicationsand slowing down ageing. J. Tradit. Chin. Med. 2012, 32, 411-414.

62. Kang, K.S.; Yamabe, N.; Kim, H.Y.; Yokozawa, T. Role of maltol in advanced glycation end products and free radicals, in vitro and in vivo studies. J. Pharm. Pharmacol. 2008, 60, 445-452.

63. Jang, D.S.; Yoo, N.H.; Kim, N.H.; Lee, Y.M.; Kim, C.S.; Kim, J.; Kim, J.H.; Kim, J.S. 3,5-Di-O-caffeoyl-epi-quinic acid from the leaves and stems of Erigeron annuus inhibits protein glycation, aldose reductase, and cataractogenesis. Biol. Pharm. Bull. 2010, 33, 329-333.

64. Harris, C.S.; Cuerrier, A.; Lamont, E.; Haddad, P.S.; Arnason, J.T.; Bennett, S.A.; Johns, T. Investigating wild berries as a dietary approach to reducing the formation of advanced glycation endproducts: Chemical correlates of in vitro antiglycation activity. Plant Foods Hum. Nutr. 2014, 69, 71-77.

65. Yoo, N.H.; Jang, D.S.; Lee, Y.M.; Jeong, I.H.; Cho, J.H.; Kim, J.H.; Kim, J.S. Anthraquinones from the roots of Knoxia valerianoides inhibit the formation of advanced glycation end products and rat lens aldose reductase in vitro. Arch. Pharm. Res. 2010, 33, 209-214.

66. Tapiero, H.; Tew, K.D.; Ba, G.N.; Mathé, G. Polyphenols: Do they play a role in the prevention of human pathologies? Biomed. Pharmacother. 2002, 56, 200-207.

67. Ramkissoon, J.S.; Mahomoodally, M.F.; Ahmed, N.; Subratty, A.H. Antioxidant and anti-glycation activities correlates with phenolic composition of tropical medicinal herbs. Asian Pac. J. Trop. Med. 2013, 6, 561-569.

68. Adisakwattana, S.; Sompong, W.; Meeprom, A.; Ngamukote, S.; Yibchok-Anun, S. Cinnamic acid and its derivatives inhibit fructose-mediated protein glycation. Int. J. Mol. Sci. 2012, 13, 1778-1789.

69. Silván, J.M.; Assar, S.H.; Srey, C.; Dolores Del Castillo, M.; Ames, J.M. Control of the Maillard reaction by ferulic acid. Food Chem. 2011, 128, 208-213.

70. Sompong, W.; Meeprom, A.; Cheng, H.; Adisakwattana, S. A comparative study of ferulic acid on different monosaccharide-mediated protein glycation and oxidative and oxidative damage in bovine serum albumin. Molecules 2013, 18, 13886-13903. 
71. Meeprom, A.; Sompong, W.; Chan, C.B.; Adisakwattana, S. Isoferulic acid, a new anti-glycation agent, inhibits fructose- and glucose-mediated protein glycation in vitro. Molecules 2013, 18 , 6439-6454.

72. Srey, C.; Hull, G.L.; Connolly, L.; Elliott, C.T.; del Castillo, M.D.; Ames, J.M. Effect of inhibitor compounds on $\mathrm{N} \varepsilon$-(carboxymethyl)lysine (CML) and $\mathrm{N} \varepsilon$-(carboxyethyl)lysine (CEL) formation in model foods. J. Agric. Food Chem. 2010, 58, 12036-12041.

73. Huang, S.M.; Chuang, H.C.; Wu, C.H.; Yen, G.C. Cytoprotective effects of phenolic acids on methylglyoxal-induced apoptosis in Neuro-2A cells. Mol. Nutr. Food Res. 2008, 52, 940-949.

74. Muthenna, P.; Akileshwari, C.; Reddy, G.B. Ellagic acid, a new antiglycating agent: Its inhibition of Ne-(carboxymethyl)lysine. Biochem. J. 2012, 442, 221-230.

75. Gugliucci, A.; Bastos, D.H.; Schulze, J.; Souza, M.F. Caffeic and chlorogenic acids in Ilex paraguariensis extracts are the main inhibitors of AGE generation by methylglyoxal in model proteins. Fitoterapia 2009, 80, 339-344.

76. Kim, J.; Jeong, I.H.; Kim, C.S.; Lee, Y.M.; Kim, J.M.; Kim, J.S. Chlorogenic acid inhibits the formation of advanced glycation end products and associated protein cross-linking. Arch. Pharm. Res. 2011, 34, 495-500.

77. Lv, L.; Shao, X.; Chen, H.; Ho, C.T.; Sang, S. Genistein inhibits advanced glycation end product formation by trapping methylglyoxal. Chem. Res. Toxicol. 2011, 24, 579-586.

78. Tarwadi, K.V.; Agte, V.V. Effect of micronutrients on methylglyoxal-mediated in vitro glycation of albumin. Biol. Trace Elem. Res. 2011, 143, 717-725.

79. Bournival, J.; Francoeur, M.A.; Renaud, J.; Martinoli, M.G. Quercetin and sesamin protect neuronal PC12 cells from high-glucose-induced oxidation; nitrosative stress; and apoptosis. Rejuvenation Res. 2012, 15, 322-333.

80. Xie, Y.; Chen, X. Structures required of polyphenols for inhibiting advanced glycation end products formation. Curr. Drug Metab. 2013, 14, 414-431.

81. Obrenovich, M.E.; Nair, N.G.; Beyaz, A.; Aliev, G.; Reddy, V.P. The role of polyphenolic antioxidants in health, disease, and aging. Rejuvenation Res. 2010, 13, 631-643.

82. Sadowska-Bartosz, I.; Galiniak, S.; Bartosz, G. Kinetics of glycoxidation of bovine serum albumin by methylglyoxal and glyoxal and its prevention by various compounds. Molecules 2014, 19, 4880-4896.

83. Sadowska-Bartosz, I.; Galiniak, S.; Bartosz, G. Kinetics of glycoxidation of bovine serum albumin by glucose, fructose and ribose and its prevention by food components. Molecules 2014, 19, $18828-18849$.

84. Rajasekar, P.; Anuradha, C.V. L-Carnitine inhibits protein glycation in vitro and in vivo, evidence for a role in diabetic management. Acta Diabetol. 2007, 44, 83-90.

85. Förster, A.; Kühne, Y.; Henle, T. Studies on absorption and elimination of dietary Maillard reaction products. Ann. N. Y. Acad. Sci. 2005, 1043, 474-481.

86. Cerami, C.; Founds, H.; Nicholl, I.; Mitsuhashi, T.; Giordano, D.; Vanpatten, S.; Lee, A.; Al-Abed, Y.; Vlassara, H.; Bucala, R.; et al. Tobacco smoke is a source of toxic reactive glycation products. Proc. Natl. Acad. Sci. USA 1997, 94, 13915-13920. 
87. Geissler, S.; Hellwig, M.; Zwarg, M.; Markwardt, F.; Henle, T.; Brandsch, M. Transport of the advanced glycation end products alanylpyrraline and pyrralylalanine by the human proton-coupled peptide transporter hPEPT1. J. Agric. Food Chem. 2010, 58, 2543-2547.

88. Koschinsky, T.; He, C.J.; Mitsuhashi, T.; Bucala, R.; Liu, C.; Buenting, C.; Heitmann, K.; Vlassara, H. Orally absorbed reactive glycation products (glycotoxins): An environmental risk factor in diabetic nephropathy. Proc. Natl. Acad. Sci. USA 1997, 94, 6474-6479.

89. Uribarri, J.; Cai, W.; Sandu, O.; Peppa, M.; Goldberg, T.; Vlassara, H. Diet-derived advanced glycation end products are major contributors to the body's AGE pool and induce inflammation in healthy subjects. Ann. N. Y. Acad. Sci. 2005, 1043, 461-466.

90. Luevano-Contreras, C.; Chapman-Novakofski, K. Dietary advanced glycation end products and aging. Nutrients 2010, 2, 1247-1265.

91. Diamanti-Kandarakis, E.; Piperi, C.; Korkolopoulou, P.; Kandaraki, E.; Levidou, G.; Papalois, A.; Patsouris, E.; Papavassiliou, A.G. Accumulation of dietary glycotoxins in the reproductive system of normal female rats. J. Mol. Med. (Berl) 2007, 85, 1413-1420.

92. Sebeková, K.; Hofmann, T.; Boor, P.; Sebeková, K., Jr.; Ulicná, O.; Erbersdobler, H.F.; Baynes, J.W.; Thorpe, S.R.; Heidland, A.; Somoza V. Renal effects of oral Maillard reaction product load in the form of bread crusts in healthy and subtotally nephrectomized rats. Ann. N. Y. Acad. Sci. 2005, 1043, 482-491.

93. Uribarri, J.; Cai, W.; Peppa, M.; Goodman, S.; Ferrucci, L.; Striker, G.; Vlassara, H. Circulating glycotoxins and dietary advanced glycation endproducts: Two links to inflammatory response, oxidative stress, and aging. J. Gerontol. A Biol. Sci. Med. Sci. 2007, 62, 427-433.

94. Sebeková, K.; Saavedra, G.; Zumpe, C.; Somoza, V.; Klenovicsová, K.; Birlouez-Aragon, I. Plasma concentration and urinary excretion of $\mathrm{N}$ epsilon-(carboxymethyl)lysine in breast milk- and formula-fed infants. Ann. N. Y. Acad. Sci. 2008, 1126, 177-180.

95. Uribarri, J.; Stirban, A.; Sander, D.; Cai, W.; Negrean, M.; Buenting, C.E.; Koschinsky, T.; Vlassara, H. Single oral challenge by advanced glycation end products acutely impairs endothelial function in diabetic and nondiabetic subjects. Diabetes Care 2007, 30, 2579-2582.

96. Uribarri, J.; Peppa, M.; Cai, W.; Goldberg, T.; Lu, M.; He, C.; Vlassara, H. Restriction of dietary glycotoxins reduces excessive advanced glycation end products in renal failure patients. J. Am. Soc. Nephrol. 2003, 14, 728-731.

97. Vlassara, H.; Cai, W.; Crandall, J.; Goldberg, T.; Oberstein, R.; Dardaine, V.; Peppa, M.; Rayfield, E.J. Inflammatory mediators are induced by dietary glycotoxins, a major risk factor for diabetic angiopathy. Proc. Natl. Acad. Sci. USA 2002, 99, 15596-15601.

98. Sohal, R.S.; Forster, M.J. Caloric restriction and the aging process: A critique. Free Radic. Biol. Med. 2014, 73, 366-382.

99. Monnier, V.M. Intervention against the Maillard reaction in vivo. Arch. Biochem. Biophys. 2003, $419,1-15$.

100. Metz, T.O.; Alderson, N.L.; Thorpe, S.R.; Baynes, J.W. Pyridoxamine, an inhibitor of advanced glycation and lipoxidation rections: A novel therapy for treatment of diabetic complications. Arch. Biochem. Biophys. 2003, 419, 41-49. 
101. Nagaraj, R.H.; Sarkar, P.; Mally, A.; Biemel, K.M.; Lederer, M.O.; Padayatti, P.S. Effect of pyridoxamine on chemical modification of proteins by carbonyls in diabetic rats: Characterization of a major product from the reaction of pyridoxamine and methylglyoxal. Arch. Biochem. Biophys. 2002, 402, 110-119.

102. Vlassopoulos, A.; Lean, M.E.; Combet, E. Protein-phenolic interactions and inhibition of glycation-combining a systematic review and experimental models for enhanced physiological relevance. Food Funct. 2014, 5, 2646-2655.

103. Stitt, A.; Gardiner, T.A.; Alderson, N.L.; Canning, P.; Frizzell, N.; Duffy, N.; Boyle, C.; Januszewski, A.S.; Chachich, M.; Baynes, J.W.; et al. The AGE inhibitor pyridoxamine inhibits development of retinopathy in experimental diabetes. Diabetes 2002, 51, 2826-2832.

104. Alderson, N.L.; Chachich, M.E.; Youssef, N.N.; Beattie, R.J.; Nachtigal, M.; Thorpe, S.R.; Baynes, J.W. The AGE inhibitor pyridoxamine inhibits lipemia and development of renal and vascular disease in Zucker obese rats. Kidney Int. 2003, 63, 2123-2133.

105. Sasaki, K.; Chiba, S.; Yoshizaki, F. Effect of natural flavonoids: Stilbenes and caffeic acid oligomers on protein glycation. Biomed. Rep. 2014, 2, 628-632.

106. Walter, A.; Etienne-Selloum, N.; Brasse, D.; Khallouf, H.; Bronner, C.; Rio, M.C.; Beretz, A.; Schini-Kerth, V.B. Intake of grape-derived polyphenols reduces C26 tumor growth by inhibiting angiogenesis and inducing apoptosis. FASEB J. 2010, 24, 3360-3369.

107. Kumar, D.; Kumar, S.; Kohli, S.; Arya, R.; Gupta, J. Antidiabetic activity of methanolic bark extract of Albizia odoratissima Benth. in alloxan induced diabetic albino mice. Asian Pac. J. Trop. Med. 2011, 4, 900-903.

108. Li, Y.N.; Guo, Y.; Xi, M.M.; Yang, P.; Zhou, X.Y.; Yin, S.; Hai, C.X.; Li, J.G.; Qin, X.J. Saponins from Aralia taibaiensis attenuate D-galactose-induced aging in rats by activating FOXO3a and Nrf2 pathways. Oxid Med. Cell. Longev. 2014, 2014, 320513.

109. Han, C.H.; Lin, Y.S.; Lee, T.L.; Liang, H.J.; Hou, W.C. Asn-Trp dipeptides improve the oxidative stress and learning dysfunctions in D-galactose-induced BALB/c mice. Food Funct. 2014, 5, 2228-2236.

110. Prisila Dulcy, C.; Singh, H.K.; Preethi, J.; Rajan, K.E. Standardized extract of Bacopa monniera (BESEB CDRI-08) attenuates contextual associative learning deficits in the aging rat's brain induced by D-galactose. J. Neurosci. Res. 2012, 90, 2053-2064.

111. Fujiwara, Y.; Kiyota, N.; Tsurushima, K.; Yoshitomi, M.; Mera, K.; Sakashita, N.; Takeya, M.; Ikeda, T.; Araki, T.; Nohara, T.; et al. Natural compounds containing a catechol group enhance the formation of $\mathrm{N} \varepsilon$-(carboxymethyl)lysine of the Maillard reaction. Free Radic. Biol. Med. 2011, 50, 883-891.

112. Zhang, S.; Dong, Z.; Peng, Z.; Lu, F. Anti-aging effect of adipose-derived stem cells in a mouse model of skin aging induced by D-galactose. PLoS One 2014, 9, e97573.

113. Zhang, B.; He, K.; Chen, W.; Cheng, X.; Cui, H.; Zhong, W.; Li, S.; Wang, L. Alagebrium (ALT-711) improves the anti-hypertensive efficacy of nifedipine in diabetic-hypertensive rats. Hypertens. Res. 2014, 37, 901-907.

114. Freidja, M.L.; Vessières, E.; Toutain, B.; Guihot, A.L.; Custaud, M.A.; Loufrani, L.; Fassot, C.; Henrion, D. AGEs breaking and antioxidant treatment improves endothelium-dependent dilation without effect on flow-mediated remodeling of resistance arteries in old Zucker diabetic rats. Cardiovasc. Diabetol. 2014, 13, 55. 
115. Sakul, A.; Cumaoğlu, A.; Aydin, E.; Ari, N.; Dilsiz, N.; Karasu, C. Age- and diabetes-induced regulation of oxidative protein modification in rat brain and peripheral tissues, consequences of treatment with antioxidant pyridoindole. Exp. Gerontol. 2013, 48, 476-484.

116. Han, J.; Tan, C.; Wang, Y.; Yang, S.; Tan, D. Betanin reduces the accumulation and cross-links of collagen in high-fructose-fed rat heart through inhibiting non-enzymatic glycation. Chem. Biol. Interact. 2015, 227C, 37-44.

117. Zhu, D.; Wang, L.; Zhou, Q.; Yan, S.; Li, Z.; Sheng, J.; Zhang, W. (+)-Catechin ameliorates diabetic nephropathy by trapping methylglyoxal in type 2 diabetic mice. Mol. Nutr. Food Res. 2014, 58, 2249-2260.

118. Muthenna, P.; Raghu, G.; Kumar, P.A.; Surekha, M.V.; Reddy, G.B. Effect of cinnamon and its procyanidin-B2 enriched fraction on diabetic nephropathy in rats. Chem. Biol. Interact. 2014, $222 C, 68-76$.

119. Ciddi, V.; Dodda, D. Therapeutic potential of resveratrol in diabetic complications: In vitro and in vivo studies. Pharmacol. Rep. 2014, 66, 799-803.

120. Brodeur, M.R.; Bouvet, C.; Bouchard, S.; Moreau, S.; Leblond, J.; Deblois, D.; Moreau, P. Reduction of advanced-glycation end products levels and inhibition of RAGE signaling decreases rat vascular calcification induced by diabetes. PLoS One 2014, 9, e85922.

121. Kim, Y.S.; Jung, D.H.; Sohn, E.; Lee, Y.M.; Kim, C.S.; Kim, J.S. Extract of Cassiae semen attenuates diabetic nephropathy via inhibition of advanced glycation end products accumulation in streptozotocin-induced diabetic rats. Phytomedicine 2014, 21, 734-739.

122. Rao, A.R.; Veeresham, C.; Asres, K. In vitro and in vivo inhibitory activities of four Indian medicinal plant extracts and their major components on rat aldose reductase and generation of advanced glycation endproducts. Phytother. Res. 2013, 27, 753-760.

123. Liu, R.; Wu, C.X.; Zhou, D.; Yang, F.; Tian, S.; Zhang, L.; Zhang, T.T.; Du, G.H. Pinocembrin protects against $\beta$-amyloid-induced toxicity in neurons through inhibiting receptor for advanced glycation end products (RAGE)-independent signaling pathways and regulating mitochondrion-mediated apoptosis. BMC Med. 2012, 10, 105.

124. Kim, J.Y.; Hong, J.H.; Jung, H.K.; Jeong, Y.S.; Cho, K.H. Grape skin and loquat leaf extracts and acai puree have potent anti-atherosclerotic and anti-diabetic activity in vitro and in vivo in hypercholesterolemic zebrafish. Int. J. Mol. Med. 2012, 30, 606-614.

(C) 2015 by the authors; licensee MDPI, Basel, Switzerland. This article is an open access article distributed under the terms and conditions of the Creative Commons Attribution license (http://creativecommons.org/licenses/by/4.0/). 